\title{
Economic Analysis of Dairy Farms in Province of Izmir
}

\author{
Nursel Koyubenbe ${ }^{1, a, *}$

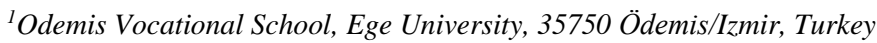

*Corresponding author

\begin{tabular}{l|l}
\hline A R T I C L E I N F O & A B S T R A C T \\
\hline Research Article & $\begin{array}{l}\text { This study aimed to analyze the economic structure of dairy cattle farms, which were members of the } \\
\text { Cattle Breeders' Association in İzmir Province. For this purpose, Ödemiş, Tire, Bayindır and Kiraz } \\
\text { districts of Izmir province were included in the study. The main material of the study consisted of } \\
\text { data obtained from the farmers through the questionnaire. The data belongs to the } 2017 \text { production } \\
\text { period. The number of farmers interviewed was determined as } 67 \text { by proportional sampling method. } \\
\text { When the data were being analyzed, farms were evaluated in three groups depending on their size. } \\
\text { According to farm groups, number of cows, respectively, was 5-14, 15-49 and over 50. In the farms } \\
\text { surveyed, the average number of animals was } 49 \text { heads, the number of milked animals was } 22 \text { heads, } \\
\text { Accepted : } 10 / 07 / 2020 \\
\text { the daily milk yield was } 22 \text { kg and the lactation yield was } 7,123 \text { kg. The total active capital of the } \\
\text { farms was } \$ 373,449 \text { and the share of animal capital in active capital was } 22 \% \text {. Total variable costs } \\
\text { per farm were } \$ 44,599, \text { fixed costs were } \$ 15,605 \text { and production costs were } \$ 60,204 . \text { Variable costs } \\
\text { constituted } 74 \% \text { of the production costs. The share of feed costs in variable costs was } 78 \% \text {. Gross } \\
\text { production value was calculated as } \$ 67,211 . \text { The share of milk sales in gross production value was } \\
61 \% \text {. Average gross profit per farm is estimated as } \$ 22,612, \text { net profit as } \$ 7,007 \text { and proportional } \\
\text { profit as } 12 \% . \text { It has been revealed that the net profit and proportional profit of small farms were } \\
\text { negative. As a result, it can be said that the profitability level of medium and large-scale farms is } \\
\text { high, whereas small scale farms meet with loses in the research region. }\end{array}$ \\
$\begin{array}{l}\text { Keywords: } \\
\text { Eairy cattle } \\
\text { Net profit }\end{array}$ \\
$\begin{array}{l}\text { Proportional profit } \\
\text { Izmir }\end{array}$
\end{tabular}

Türk Tarım - Gıda Bilim ve Teknoloji Dergisi, 8(10): 2236-2242, 2020

\section{İzmir İlinde Süt Sı ğırcılığı İşletmelerinin Ekonomik Analizi}

\begin{tabular}{|c|c|}
\hline M A K A L E B İ L G İ S İ & Ö Z \\
\hline $\begin{array}{l}\text { Anahtar Kelimeler: } \\
\text { Süt sığırcılığı } \\
\text { Ekonomik analiz } \\
\text { Net kar } \\
\text { Oransal kar } \\
\text { İzmir }\end{array}$ & 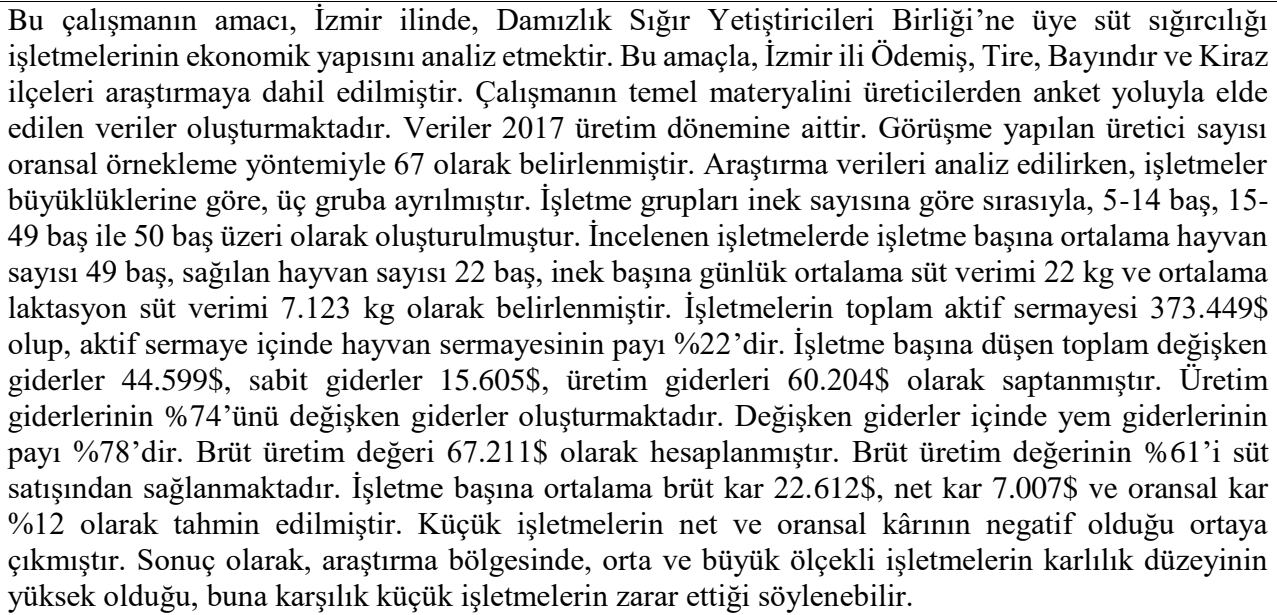 \\
\hline
\end{tabular}




\section{Giriş}

İnsanların yeterli ve dengeli beslenmesi ve sağlıklı bir hayat sürdürmesi ancak belirli miktarda hayvansal kaynaklı protein tüketmeleri ile mümkündür. Hayvansal kaynaklı gıda üretiminde sığırcıllğın çok önemli bir payı bulunmaktadır. Hayvancılık sektörü; beslenmenin yanında, bitkisel üretimin aksine yllın hemen tamamına yayılan ve üretici gelirlerini sürekli kılan bir faaliyettir (Öztürk ve Karkacier, 2008). Ayrıca atıl işgücünün değerlendirilmesi, işletmede riskin ve kırsal alandan göçün azaltılması açısından da oldukça önemlidir (Yıldırım ve Şahin 2003).

Türkiye'deki 2019 yılı toplam tarımsal üretim değeri yaklaşık 455 milyar TL olarak gerçekleşmiştir. Toplam tarımsal üretim değerinin yaklaşık \%57 (259 milyar TL)'sini canlı hayvan ve hayvansal üretim değerleri oluşturmaktadır. Hayvancılık üretim değeri içinde canlı hayvan üretim değerinin payı \%64 (165 milyar TL) iken, hayvansal ürünler üretim değerinin payı \%36 (94 milyar TL)'dır (TUIK, 2020a). Hayvansal ürünler üretim değerlerinin, canlı hayvan üretim değerlerinden yaklaşık \%28 oranında daha düşük gerçekleşmesi, hayvansal üretimde verimlilik sorunlarının olduğunu göstermektedir.

2019 yılı verilerine göre, Türkiye'de büyük baş sığır varlı̆ğının \%48'ini yüksek verimli kültür ırk1, \%43'ünü melez ırk ve \%9'unu düşük verimli yerli rrk sığırlar oluşturmaktadır. Toplam sağılan sığır sayısı 6.580 .753 baş, toplam süt üretimi 22.960 .379 tondur (TUIK, 2020b).

2019 yılı verilerine göre, Türkiye toplam süt üretimi içinde İzmir ili, yaklaşık \%5 oranındaki (1.186.710 ton) payı ile Konya ilinden sonra ikinci sırada yer almaktadır (TUIK, 2020b). Dolayısıyla bölgede geniş bir üretim potansiyeli mevcuttur. Bu nedenle araştırma alanı olarak İzmir ili seçilmiştir. İzmir ili içinde ise, süt üretiminin \%71,8'ini (GTHB, 2017) oluşturan Ödemiş, Tire, Kiraz ve Bayındır ilçelerindeki süt sığırcılığı işletmelerini kapsamaktadır.

Dünyada ve Türkiye'de süt sığırcıllı̆ı işletmelerinin ekonomik analizi ile ilgili çalışmalar oldukça fazla sayıdadır (Bayramoğlu, 2003; Bayramoğlu ve Direk, 2006; Demircan ve ark., 2006; Öztürk ve Karkacier, 2008; Özüdoğru, 2010; Uddin ve ark., 2010; Keskin ve Dellal, 2011; Murat, 2011, Tokmak ve ark., 2011; Venkatesh ve Sangeetha, 2011; Lapple ve ark. 2012; Mumba ve ark., 2012; Murat ve Sakarya, 2012; Ata ve Y1lmaz, 2015; Semerci ve ark., 2015; Hanrahan ve ark., 2017; Oğuz ve Yener, 2017; Özsayın, 2019). Ancak İzmir ilinde en son 1993 yılında yapılan çalışma (Saner, 1993) dışında bu tür bir bilimsel çalışmaya rastlanılmamıştır. Süt sığırcılığ faaliyetlerinin ekonomik yönden değerlendirilmesi, kaynakların etkin kullanılıp kullanılmadığını göstermektedir. Kaynakların etkin kullanımıyla ilgili bilgilerin olmaması değerlendirme yapmayı imkansız hale getirirken, konuyla ilgili araştırmaların yapılması gerektiğini ve konunun önemini de ortaya koymaktadır.
İzmir ili süt sığırcilığı işletmelerini konu alan bu çalışmanın esas amacı; süt sığırcılığı işletmelerinin sosyal ve ekonomik yapılarını belirlemek, bu yapı içerisinde işletmelerin sermaye yapısını, gelir ve gider unsurları ile yıllık faaliyet sonuçlarını ortaya koymaktır.

\section{Materyal ve Yöntem}

$\mathrm{Bu}$ çalışmanın temel materyalini üreticilerden anket yoluyla elde edilen veriler oluşturmaktadır. Veriler, Eylül 2016 ile Eylül 2017 arasındaki üretim dönemine dayanmaktadır. Çalışmanın verileri, Ödemiş, Tire, Bayındır ve Kiraz ilçelerinde İzmir İli Damızlık Sığır Yetiştiricileri Birliği (IDSYB)'ne kayıtlı işletmelerden elde edilmiştir. Bu ilçelerde İDSYB'ne kayıtlı toplam 11.080 adet süt sığırcıllı̆̆ işletmesi bulunmaktadır (IDSYB, 2017). Görüş̧me yapılan üretici sayısı oransal örnekleme yöntemiyle (Newbold, 1995) belirlenmiştir. Maksimum örnek hacmine ulaşabilmek için yetiştirici oranı 0,50 olarak alınmış ve 67 üretici ile görüşülmüştür.

$$
\mathrm{n}=\frac{\mathrm{N}_{\mathrm{p}}(1-\mathrm{p})}{(\mathrm{N}-1) \sigma_{\mathrm{px}}^{2}+\mathrm{p}(1-\mathrm{p})}
$$

$\mathrm{n} \quad$ : Örnek hacmi,

N : Havzada süt hayvancılı̆̆ı yapan toplam işletme sayısı (11.080)

$$
\begin{aligned}
& \sigma_{\mathrm{px}}^{2}: \text { Varyans }(0,06079) \\
& \mathrm{P}: \text { Süt hayvancılığı yapan yetiştirici oranı }(0,50)
\end{aligned}
$$

Toplanan veriler analiz edilirken, işletmeler inek sayılarına göre 3 gruba ayrılmıştır (Çizelge 1). Grupları oluştururken inek sayıları, İzmir' in 5 inek ve üzerinde hayvana sahip işletmelerin toplam içindeki oransal dağılımı dikkate alınarak belirlenmiştir. Her gruptan görüşülecek olan yetiştirici sayısı oransal olarak hesaplanmıştır.

Elde edilen veriler SPSS istatistik programı yardımıyla değerlendirilmiştir. İşletme grupları arasında farklılıkların olup olmadığını ortaya koymak amacıyla normal dağılış gösteren değişkenlerde varyans analizi, normal dağılış göstermeyen değişkenlerde Kruskall-Wallis testi kullanılmıştır (Miran, 2002)

İncelenen işletmelerde aile işgücü mevcudunun hesaplanmasında; öncelikle işletmelerdeki nüfus erkek iş birimine (EİB) dönüștürülmüștür. İşletmelerdeki nüfusun erkek iş birimine dönüştürülmesinde; 7-14 yaş grubundaki erkek ve kadın için 0,$50 ; 15-49$ yaş grubundaki erkek için 1,00 ; kadın için 0,75 ; 50-64 yaş grubundaki erkek için 0,75; kadın için 0,50 katsayıları kullanılmıştır (Aras, 1988). Daha sonra, günde 10 saat hesab1 ile yılda 300 gün çalışan yetişkin bir erkek işçi (15-49 yaşları arası), bir erkek işgücü birimi kabul edilmiş ve aile işgücü potansiyeli bu ölçüye göre erkek iş gününe (EİG) dönüştürülmüştür.

Çizelge 1. İnek sayılarına göre işletme grupları ve işletme sayıları

Table 1. (Farm Groups According to Cow Numbers and Number of Farms)

\begin{tabular}{l|cc}
\hline \multicolumn{1}{c|}{ İşletme Gruplar1 } & İnek Say1s1 & Issletme Say1s1 \\
\hline 1.Grup & $05-14$ & 34 \\
2.Grup & $15-49$ & 25 \\
3.Grup & $50+$ & 87 \\
\hline Toplam & & 67 \\
\hline
\end{tabular}


Karşılaștırma kolaylığı sağlaması açısından parasal değerler TL yerine dolar olarak ifade edilmiştir. 2017 y1lı için bir Dolar ortalama 3,65 TL olarak hesaplanmıştır (TCMB, 2020).

$\mathrm{Bu}$ çalışmada, sermaye yapısının oluşturulmasında fonksiyonel sınıflandırma esas alınmıştır (Açıl ve Demirci, 1984; İnan, 1994). Aktif sermaye, arazi ve işletme sermayesinden oluşmaktadır. Arazi sermayesi, toprak ve bina (işletmenin süt sığırcılığında kullandığı barınaklar, yem depoları, silolar ve diğer binaların edinim bedelleri dikkate alınarak hesaplanmıştır) sermayelerini kapsamaktadır. Hayvan sermayesi (işletmenin dönem sonunda sahip olduğu inek, düve, dana ve damızlık boğaların değerleri), alet makina sermayesi (işletmede süt üretiminde kullanılan alet-makinaların alım değerleri), malzeme sermayesi (işletmede tüketilen yem ve akaryakıt değerleri) ve nakit para sermayesi (işçilik, bakım ve onarım giderleri, toplam amortisman karşılıkları ile diğer giderleri karşılamak üzere banka ya da kasada işletme emrine hazır olarak bulundurulan nakit para) işletme sermayesinin tamamını oluşturmaktadır.

Süt üretiminde yıllık faaliyet sonuçları aşağıdaki şekilde hesaplanmıştır (Kıral ve ark., 1999).

Değişken giderler; kesif yem, kaba yem, geçici işgücü, veteriner ve sağlık (veteriner, ilaç ve suni tohumlama masrafları), makina tamir-bakım, akaryakıt, elektrik-su ve diğer (vitamin, tuz, altlık ve temizlik) giderlerin toplamından oluşmuştur. Sabit giderler; idari giderler (değişken giderlerin \%3'ü), aile işgücü ücret karşılığ 1 , daimi işgücü giderleri, amortismanlar (bina, alet-makina ve hayvan amortismanı toplamı), faiz (bina, alet-makina ve hayvan sermayesi faizlerinin toplamı) ve bina tamir bakım giderlerinin toplanması ile elde edilmiştir. Üretim giderleri, değişken giderler ve sabit giderlerin toplanmasıyla hesaplanmıştır.

Bina, alet-makina ve inek amortismanı değerlerini hesaplamak için doğru hat yöntemi kullanılmıştır (Kıral ve ark., 1999). Bina (BSF), Alet-makine (AMSF) ve İnek sermayesinin (ISF) faiz giderlerini hesaplamak için;

$\mathrm{BSF}=($ Bina değeri + Hurda değeri $) / 2 \times$ Faiz oranı,

$\mathrm{AMSF}=($ Alet-makina değeri + Hurda değeri $) / 2 \times$ Faiz oran 1

İSF= (Damızlık değeri + Kasaplık değeri $) / 2 \times$ Faiz oranı

formülleri kullanılmıştır (Kıral ve ark., 1999).
Brüt üretim değeri; süt üretim değeri, hayvan satış değeri, envanter değer artışı ve çiftlik gübresi satış değerinden oluşmuştur. Envanter değer artış1; yıl sonu hayvan değeri, satılan ve kesilen hayvan değeri toplamından, yıl başı hayvan değeri ile satın alınan hayvan değeri toplamının çıkarılması sonucu elde edilmiştir.

Brüt kar, brüt üretim değerinden toplam değişken giderlerin çıkarılmasıyla elde edilmiştir. Net kar, brüt üretim değerinden üretim giderleri çıkartılarak, oransal kar ise brüt üretim değerini üretim giderlerine bölmek suretiyle hesaplanmıştır (Kıral ve ark., 1999).

\section{Bulgular ve Tartışma}

\section{İncelenen İşletmelerin Genel Özellikleri}

İncelenen süt sı̆̆ırcılığı işletmelerindeki üreticilerin ortalama yaşı 46; ortalama eğitim süresi 8 yıl ve ortalama süt sığırcılığı deneyimi 17 yıldır (Çizelge 2). Büyük işletmelerin yer aldığı 3 . gruptaki üreticilerin daha genç, daha eğitimli ve daha tecrübeli oldukları belirlenmiştir. Görüşülen üreticilerin \%69'i tarımsal amaçlı bir kooperatife ortaktır. Gruplar itibariyle incelendiğinde en yüksek kooperatifleşme oranı 1. grupta; en düşük kooperatifleşme oranı 3. gruptadır. Ziraat Odasına üye olan üreticilerin oranı \%96'dir (Çizelge 2). Dolayısıyla süt sığırcılığı işletmelerinin mesleki örgütlenmelerinin ekonomik örgütlenmelerinden daha iyi olduğu söylenebilir. Ancak Ziraat Odası üyeliğinin dekar başına ödenen Doğrudan Gelir Desteği uygulaması başladığından bu yana artması da göz ardı edilmemelidir. Üye olmayan üreticilerin tamamının 1. grupta yer alan küçük üreticiler olması ve bu üreticilerin genellikle tapulu toprağ 1 bulunmaması da bunu destekler niteliktedir.

İncelenen işletmelerin ortalama arazi genişliği 54 dekar olup, ortalama parsel sayısı 4 ve ortalama parsel genişliği 13 dekar olarak belirlenmiştir (Çizelge 2). Gruplar itibariyle incelendiğinde, arazi parçalanmasının en yüksek olduğu grup 3. grup iken en düşük olduğu grup 1. gruptur. İncelenen işletmelerde, toplam arazi içerisinde yem bitkisi ekilen arazi önemli bir paya sahip olup, çoğunlukla silajlık misır üretimi yapılmaktadır. Bunun yanında kaba yem olarak fiğg, yulaf, hasıl, şalgam, yonca ve karamba yetiştirilmektedir. Diğer yandan dane mısır, dane buğday ve dane arpa gibi kesif yem bitkileri üretimine ise daha az rastlanmaktadır. İşletmelerde ikinci ürün olarak silajlık misırın yanı sıra, patates, bostan gibi yazlık sebzelerin üretimi de yapılmaktadır.

Çizelge 2. İncelenen işletmelerin genel özellikleri

Table 2. General characteristics of the farms examined

\begin{tabular}{|c|c|c|c|c|}
\hline İşletmelerin Özellikleri & 1. Grup & 2. Grup & 3. Grup & Ortalama \\
\hline İşletmecinin yaşı (yıl) & 50 & 43 & 40 & 46 \\
\hline İşletmecinin eğitimi (y1l) & 7 & 8 & 9 & 8 \\
\hline İşletmecinin tecrübesi (yıl) & 15 & 18 & 21 & 17 \\
\hline Tarımsal kooperatif üyeliği (\%) & 74 & 72 & 38 & 69 \\
\hline Ziraat Odası üyeliği (\%) & 91 & 100 & 100 & 96 \\
\hline İşletmenin arazi varlığı (dekar) & 15 & 90 & 108 & 54 \\
\hline Parsel sayısı & 3 & 6 & 6 & 4 \\
\hline Ortalama parsel genişliği (dekar) & 6 & 16 & 18 & 13 \\
\hline İnek sayısı (baş) & 9 & 26 & 64 & 22 \\
\hline Toplam hayvan sayısı (baş) & 19 & 60 & 147 & 49 \\
\hline İnek-Toplam hayvan oran1 (\%) & 46 & 43 & 43 & 44 \\
\hline Günlük süt verimi $(\mathrm{kg} / \mathrm{head})$ & 21 & 23 & 23 & 22 \\
\hline Laktasyon süresi (gün) & 323 & 320 & 317 & 321 \\
\hline Laktasyon süt verimi (kg/yıl) & 6.944 & 7.326 & 7.380 & 7.123 \\
\hline
\end{tabular}


İşletmelerin toplam işgücü potansiyeli 1,4 EİB ve 420 EİG olarak saptanmıştır. İşletmelerde aile işgücü potansiyelinin \%61'ini 15-49 yaş grubundaki, \%21'ini 5064 yaş grubundaki ve \%18'ini 7-14 yaş grubundaki nüfus oluşturmaktadır. İncelenen işletmelerde, kullanılan toplam işgücünün \%53'ü daimi işgücü, \%42'si aile işgücü ve $\% 4$ 'ü geçici işgücünden oluşmaktadır.

Süt sığırcılığı işletmelerinde sermayenin önemli bir kısmını oluşturan hayvan varlığı incelendiğinde, işletmelerin ortalama hayvan sayısının 49 baş, ortalama inek sayısının 22 baş olduğu görülmektedir (Çizelge 2). İncelenen süt sığırcılığı işletmelerinde erkek hayvanlar genellikle besiye alınmayıp, küçük yaşlarda satılmaktadır. Ancak işletmeler büyüdükçe süt sığırcılığının yanında besi sığırcılığı da yapılmaya başlanmaktadır. Nitekim sağmal hayvan sayısı-toplam hayvan sayısı oranının küçük işletmelerde en yüksek (\%46) olması da bu eğilimi desteklemektedir. İncelenen işletmelerde işletme büyüklüklerine göre inek başına ortalama süt verimleri Çizelge 2'de verilmiştir. Çizelgeden görüldüğü gibi inek başına ortalama günlük süt verimi 22 kilogram, laktasyon verimi $7.123 \mathrm{~kg}$ dır. İnek başına günlük süt verimi ve laktasyon verimi işletmeler büyüdükçe artmaktadır $(\mathrm{P}<0,005)$. İnek başına ortalama günlük süt verimi, çeşitli illerde yapılan diğer birçok çalışmada (Günlü ve ark., 2001, Şahin, 2001; Şahin ve ark., 2001; İçöz, 2004; Öztürk ve Karkacier, 2008; Özüdoğru, 2010; Yılmaz, 2010; Gündüz ve Dağdeviren, 2011; Keskin ve Dellal, 2011; Tokmak ve ark., 2011; Murat ve Sakarya, 2012; Demir ve ark., 2014; Ata ve Yılmaz, 2015; Semerci ve ark., 2015; Özsayın, 2019) bildirilen sonuçlardan daha yüksek, Konya ilinde Oğuz ve Yener (2017) tarafindan yapılan çalışmada bildirilen sonuçtan daha düşük bulunmuştur. Bu çalışmada hayvan başına süt veriminin yüksek olmasının birden fazla nedeni olduğu söylenebilir. Bunlardan biri, araştırma bölgesinde süt verimi yüksek kültür ırkı süt sığırlarının yaygın olmasıdır. Bunun dışında incelenen işletmeler genellikle hem entansif süt sığırcılığı yapmakta hem de ihtisaslaşmış işletmelerden oluşmaktadır.

\section{Incelenen İşletmelerde Süt Sı̆̆̆ırcılı̆̆ı Üretim Dalında Sermaye Durumu}

Sermaye yapısının oluşturulmasında esas alınan fonksiyonel sınıflandırmaya göre incelenen işletmelere ait aktif ve pasif sermaye değerleri Çizelge 3 'te verilmiştir. Buna göre, tüm işletmeler dikkate alındığında ortalama aktif sermaye değeri 373.449 \$'dır. İşletmeler genelinde, arazi sermayesi $(\% 40)$ en büyük payı almakta ve bunu hayvan sermayesi (\%22) ve bina sermayesi (\%19) izlemektedir. Rasyonel olarak çalışan bir işletmede sermayenin, \%25'inin toprak sermayesi, \%25'inin bina sermayesi, \%25'inin hayvan sermayesi, \%10'unun aletmakine sermayesi, \%10'unun malzeme sermayesi ve \%5'inin para sermayesi şeklinde dağılması gerektiği ifade edilmektedir (Erkuş ve ark. 1996). Bu çalışmada arazi sermayesi aktif sermaye içinde en yüksek paya sahip iken, işletme sermayesinin payının düşük düzeyde kaldığı görülmektedir. Benzer şekilde daha önce yapılan birçok araştırmada da, aktif sermaye içinde arazi sermayesinin payının daha yüksek olduğu saptanmıştır (Saner, 1993, Bayramoğlu, 2003; Nizam, 2006; Altıntaş ve Akçay, 2007; Öztürk ve Karkacıer, 2008; Özüdoğru, 2010; Tokmak ve ark., 2011; Oğuz ve Yener, 2017). Bu durum işletmelerin ileri teknoloji uygulamalarını engellenmesi yanında, arazi sermayesi unsurlarının verimliliğini de olumsuz yönde etkilemektedir.

İncelenen işletmelerde toplam pasif sermaye içinde öz sermaye oran $1 \% 98$, yabanc1 sermaye oran 1 ise $\% 2$ olarak belirlenmiştir (Çizelge 3). Bu durum, tarım işletmelerinin sermaye eksikliklerinin kredi kurumlarınca rasyonel olarak giderilemediğini göstermektedir.

Gruplar itibariyle incelendiğinde, işletmeler büyüdükçe arazi ve bina sermayelerinin mutlak olarak artarken, oransal olarak azaldığ 1 görülmektedir $(\mathrm{P}<0,05)$. Hayvan sermayesi ise hem mutlak hem de oransal olarak artmaktadır $(\mathrm{P}<0,05)$.

\section{İncelenen işletmelerde süt sı̆̆ırcılı̆̆ı üretim dalı yıllık faaliyet sonuçları}

Süt sı̆̆ırcllı̆̆ üretim dalına ait değişken, sabit ve üretim giderleri

İncelenen işletmelerde işletme büyüklüklerine göre, süt sığırcılığı değişken giderleri Çizelge 4'te verilmiştir. Görüldüğü gibi, işletmeler genelinde ortalama değişken giderler 44.599 \$’ dır. Değişken gider unsurları içinde ortalama $\% 45$ ile kesif yem giderleri ilk sırayı almış, bunu \%33 ile kaba yem giderleri izlemiştir. Daha sonra sırasıyla akaryakıt $\% 7$, veteriner ve sağlık giderleri $\% 6$ ve aletmakina tamir-bakım giderleri $\% 3$, elektrik-su giderleri $\% 3$, geçici işçilik giderleri $\% 2$ oranında bir pay almıştır. Dolayısıyla değişken giderlerin içinde en büyük payı (\%77) yem giderleri oluşturmaktadır. Diğer çalışmalarda da toplam yem (kesif yem+kaba yem) giderlerinin değişken giderlerin içindeki payı $\% 80$ ve üzerinde hesaplanmıştır (Şahin, 2001; Bayramoğlu, 2003; Demircan ve ark. 2006; Tokmak ve ark., 2011; Ata ve Yilmaz, 2015; Oğuz ve Yener, 2017).

Çizelge 3. İncelenen işletmelerde aktif ve pasif sermaye değerleri (\$) ve oransal dağılımı (\%)

Table 3. Active and passive capital values in the farms surveyed (\$) and distribution (\%)

\begin{tabular}{|c|c|c|c|c|c|c|c|c|}
\hline \multirow{2}{*}{ Sermaye Türü } & \multicolumn{2}{|c|}{ 1.Grup } & \multicolumn{2}{|c|}{ 2.Grup } & \multicolumn{2}{|c|}{ 3.Grup } & \multicolumn{2}{|c|}{ Ortalama } \\
\hline & Değer & $\%$ & Değer & $\%$ & Değer & $\%$ & Değer & $\%$ \\
\hline Yem bitkisi arazisi & 61.644 & 37 & 197.508 & 43 & 249.479 & 29 & 147.955 & 40 \\
\hline Bina & 49.154 & 29 & 74.916 & 17 & 160.445 & 18 & 72.055 & 19 \\
\hline Hayvan & 29.251 & 17 & 100.599 & 22 & 254.675 & 29 & 82.789 & 22 \\
\hline Alet-ekipman & 10.811 & 6 & 32.631 & 7 & 64.538 & 7 & 25.367 & 7 \\
\hline Malzeme & 13.125 & 8 & 38.053 & 8 & 117.652 & 14 & 34.908 & 9 \\
\hline Nakit para & 5.140 & 3 & 12.602 & 3 & 25.656 & 3 & 10.375 & 3 \\
\hline Aktif Sermaye & 169.125 & 100 & 456.309 & 100 & 872.445 & 100 & 373.449 & 100 \\
\hline Yabancı sermaye & 2.659 & 2 & 6.520 & 1 & 42.465 & 5 & 8.853 & 2 \\
\hline Özsermaye & 166.466 & 98 & 449.789 & 99 & 829.980 & 95 & 364.596 & 98 \\
\hline Pasif Sermaye & 169.125 & 100 & 456.309 & 100 & 872.445 & 100 & 373.449 & 100 \\
\hline
\end{tabular}


Çizelge 4. İncelenen işletmelerde değişken, sabit, üretim giderleri (\$) ve oransal dağılımı (\%)

Table 4. Variable, fixed, production expenses (\$) and distribution (\%) in the farms examined

\begin{tabular}{|c|c|c|c|c|c|c|c|c|}
\hline \multirow{2}{*}{ Gider Türü } & \multicolumn{2}{|l|}{ 1.Grup } & \multicolumn{2}{|l|}{ 2.Grup } & \multicolumn{2}{|l|}{ 3.Grup } & \multicolumn{2}{|l|}{ Ortalama } \\
\hline & Değer & $\%$ & Değer & $\%$ & Değer & $\%$ & Değer & $\%$ \\
\hline \multicolumn{9}{|l|}{ Değişken Giderler } \\
\hline Kesif yem & 7.711 & 45 & 20.133 & 41 & 72.835 & 50 & 20.122 & 45 \\
\hline Kaba yem & 5.414 & 31 & 17.920 & 36 & 44.817 & 31 & 14.785 & 33 \\
\hline Geçici işçi & 336 & 2 & 1.077 & 2 & 1.563 & 1 & 759 & 2 \\
\hline Veteriner ve sağlık & 923 & 5 & 2.880 & 6 & 8.808 & 6 & 2.595 & 6 \\
\hline Makina tamir-bakım & 675 & 4 & 2.066 & 4 & 3.836 & 3 & 1.572 & 3 \\
\hline Akaryakıt & 1.132 & 7 & 3.625 & 7 & 8.271 & 6 & 2.915 & 7 \\
\hline Elektrik-su & 855 & 5 & 1.458 & 3 & 3.678 & 2 & 1.417 & 3 \\
\hline Diğer ${ }^{(1)}$ & 206 & 1 & 393 & 1 & 1.531 & 1 & 434 & 1 \\
\hline Toplam & 17.252 & 100 & 49.552 & 100 & 145.339 & 100 & 44.599 & 100 \\
\hline \multicolumn{9}{|l|}{ Sabit Giderler } \\
\hline İdari giderler ${ }^{(2)}$ & 518 & 6 & 1.487 & 8 & 4.360 & 13 & 1.338 & 9 \\
\hline Aile işgücü ücret karşılı̆̆ 1 & 3.414 & 39 & 6.251 & 33 & 7.279 & 21 & 4.934 & 31 \\
\hline Daimi işgücü & 0 & 0 & 1.184 & 6 & 1.027 & 3 & 564 & 4 \\
\hline Amortisman $^{(3)}$ & 2.494 & 28 & 5.368 & 28 & 10.946 & 32 & 4.576 & 29 \\
\hline Faiz $^{(4)}$ & 1.938 & 22 & 4.064 & 22 & 8.979 & 26 & 3.572 & 23 \\
\hline Bina tamir-bakım & 405 & 5 & 493 & 3 & 1.935 & 5 & 621 & 4 \\
\hline Toplam & 8.769 & 100 & 18.847 & 100 & 34.526 & 100 & 15.605 & 100 \\
\hline \multicolumn{9}{|l|}{ Üretim Giderleri } \\
\hline Değişken Giderler & 17.252 & 66 & 49.552 & 72 & 145.339 & 81 & 44.599 & 74 \\
\hline Sabit giderler & 8.768 & 34 & 18.846 & 28 & 34.527 & 19 & 15.605 & 26 \\
\hline Toplam & 26.020 & 100 & 68.398 & 100 & 179.866 & 100 & 60.204 & 100 \\
\hline
\end{tabular}

(1) Vitamin, tuz, temizlik vb., ${ }^{(2)}$ Değişken giderlerin \%3'ü hesaplanmıştır, ${ }^{(3)}$ Bina, alet-makina ve hayvan amortismanı toplamı, ${ }^{(4)}$ Bina, alet-makina ve hayvan sermayesi faizlerinin toplamı

Çizelge 5. İncelenen işletmelerde brüt üretim değeri (\$) ve oransal dağılımı (\%)

Table 5. Gross production value (\$) and distribution (\%) in the farms examined

\begin{tabular}{|c|c|c|c|c|c|c|c|c|}
\hline \multirow{2}{*}{ Gelir Türü } & \multicolumn{2}{|c|}{ 1.Grup } & \multicolumn{2}{|c|}{ 2.Grup } & \multicolumn{2}{|c|}{ 3.Grup } & \multicolumn{2}{|c|}{ Ortalama } \\
\hline & Değer & $\%$ & Değer & $\%$ & Değer & $\%$ & Değer & $\%$ \\
\hline Süt satış değeri & 14.013 & 59 & 48.146 & 60 & 130.382 & 62 & 40.644 & 61 \\
\hline Buzağı satış değeri & 2.786 & 12 & 9.658 & 12 & 20.796 & 10 & 7.501 & 11 \\
\hline Envanter değer artış1 & 6.704 & 28 & 22.027 & 27 & 57.192 & 27 & 18.450 & 27 \\
\hline Gübre satış değeri & 296 & 1 & 497 & 1 & 2.355 & 1 & 616 & 1 \\
\hline Brüt üretim Değeri & 23.799 & 100 & 80.328 & 100 & 210.725 & 100 & 67.211 & 100 \\
\hline
\end{tabular}

İncelenen işletmelerde işletme başına toplam sabit giderler ortalaması 15.605 \$ olarak saptanmıştır (Çizelge 4). Ortalama olarak sabit giderler içinde en büyük payı aile işgücü ücret karşıllı̆ı $(\% 31)$, almaktadır. Daha sonra sirasiyla amortisman giderleri $(\% 29)$, faiz $(\% 23)$, idari giderler (\%9), daimi işçilik giderleri $(\% 4)$ ve bina tamirbakım giderleri (\%4) gelmektedir.

Üretim giderleri 60.204 \$ olarak hesaplanırken büyük kısmını \%74 ile değişken giderler oluşturmuştur (Çizelge 4). İşletmeler büyüdükçe değişken giderlerin hem mutlak hem de oransal olarak arttığı, sabit giderlerin mutlak olarak artarken oransal olarak azaldığı görülmektedir.

Süt sı̆̆grrcllı̆ğ üretim dalında brüt üretim değeri

Araştırma kapsamına alınan işletmelerde işletme büyüklüklerine göre, brüt üretim değerini oluşturan süt satış geliri, buzağı geliri, hayvan envanter değer artışı ve gübre gelirinin dağılımı Çizelge 5 'te verilmiştir. Çizelgeden görüldüğü gibi işletme başına ortalama brüt üretim değeri 67.211 \$'dır. İncelenen işletmelerde brüt üretim değeri içinde en yüksek pay1 $\% 61$ ile süt satış geliri almaktadır. Envanter değer artışının toplam gelir içindeki pay1 $\% 27$ ve buzağı gelirinin pay1 $\% 11$ olurken, en düşük pay1 $\% 1$ ile gübre geliri almaktadır.
Brüt üretim değeri içinde saptadığımız süt gelirinin oransal değeri, Şahin ve ark. (2001), Bayramoğlu ve Direk (2006), Nizam (2006), Gündüz ve Dağdeviren (2011), Murat (2011), Demir ve ark., (2014), Ata ve Yilmaz (2015), Semerci ve ark. (2015), Oğuz ve Yener (2017), Özsayın (2019)'ın bildirdiği değerlerden düşük, envanter değer artışının oransal değeri ise söz konusu çalışmalardan daha yüksek bulunmuştur. Bunun tersine süt gelirinin oransal değeri, Günlü ve ark. (2001), İçöz (2004), Demircan ve ark., (2006), Tandoğan (2006), Özüdoğru (2010)'nun bildirdiği değerlerden yüksek, envanter değer artişı daha düşük bulunmuştur.

İşletme büyüklüklerine göre değerlendirildiğinde, işletme büyüklüğü arttıkça işletme gelirleri içindeki süt gelirlerinin payının da arttı̆g saptanmıştır $(\mathrm{P}<0,005)$. Bu artış, büyük işletmelerde hayvan sayısının dolayısıyla süt miktarının fazla olmasının yanında, süt veriminin ve süt fiyatının daha yüksek olmasından kaynaklanmaktadır. Bunun yanında buzağı satış değerinin işletmeler büyüdükçe mutlak olarak artarken, oransal olarak azalması da dikkat çekicidir. Bunun, büyük işletmelerin erkek hayvanları besleme eğilimini daha fazla olmasından kaynaklandığı söylenebilir. 
Süt sı̆̆ırcllı̆ğ üretim dalında brüt kar, net kar ve oransal kar

Brüt kar değerleri işletme grupları itibariyle Çizelge 6'da verilmiştir. İncelenen işletmelerde, işletmelerin ortalama brüt kârı 22.612 \$'dır. Brüt karın brüt üretim değeri içindeki payı küçük işletmelerde \%28, orta ölçekli işletmelerde $\% 38$, büyük işletmelerde $\% 31$ ve işletmeler genelinde \%34'tür. Dolayısıyla incelenen işletmelerin elde ettiği gelir ile sabit giderlerini karşılayacak güce sahip olduğu söylenebilir. Bu sonuç, daha önce Konya ilinde yapılan iki çalışma (Bayramoğlu, 2003; Bayramoğlu ve Direk, 2006) ve Niğde ilinde yapılan çalışmanın (Tokmak ve ark., 2011) sonuçlarına benzer, Burdur ilinde yapılan çalışmanın (Ata ve Yılmaz, 2015) sonucundan ise daha yüksektir. Buna karşılık Adana ilinde Şahin ve ark. (2001), Kayseri ilinde Şahin (2001), Amasya ilinde Özüdoğru (2010), Trakya bölgesinde Keskin ve Dellal (2011), Konya ilinde Oğuz ve Yener (2017), Bursa ilinde Özsayın (2019) tarafindan yapılan çalışmalarda bulunan sonuçlar, bu çalışmadaki sonuçlardan daha yüksektir.
İncelenen işletmelerde ortalama net kar 7.007 , net kârın brüt üretim değeri içindeki payı \%10 olarak saptanmıştır (Çizelge 6). Bu sonuç, Burdur ilinde Demircan ve ark. (2006), Hatay ilinde Semerci ve ark., (2015), Bursa ilinde Özsayın (2019) tarafindan yapılan çalışmalarda bildirilen sonuçlardan daha yüksek, Konya'da Oğuz ve Yener (2017) tarafindan bulunan sonuçtan ise daha düşüktür. Yine Konya ilinde yapılan bir çalışmada (Bayramoğlu ve Direk, 2006) net kâr, negatif olarak tahmin edilmiştir. İncelenen işletmelerde oransal kar \%12 olarak hesaplanmıştır (Çizelge 6). Bu sonuç, söz konusu işletmelerin yaptığ ortalama 12 birim kar elde ettiği anlamına gelmektedir. Oransal kar, bu konuda daha önce yapılan çalışmalardan (Demircan ve ark., 2006; Semerci ve ark., 2015; Özsayın, 2019) daha yüksek bulunmuştur. İşletme büyüklükleri dikkate alındığında, hem 2 . hem de 3 . gruptaki işletmelerin oransal kârının \%18 olduğu görülmektedir. Buna karşılık 1. gruptaki işletmelerin, 100 birimlik masrafa karşılık ortalama 9 birim zarar ettiği anlaşılmaktadır.

Çizelge 6. İncelenen işletmelerde brüt kar (\$), net kar (\$) ve oransal kar

Table 6. Gross profit (\$), net profit (\$) and proportional profit in the examined farms

\begin{tabular}{|c|c|c|c|c|c|c|c|c|}
\hline & \multicolumn{2}{|c|}{ 1.Grup } & \multicolumn{2}{|c|}{ 2.Grup } & \multicolumn{2}{|c|}{ 3.Grup } & \multicolumn{2}{|c|}{ Ortalama } \\
\hline & Değer & $\%$ & Değer & $\%$ & Değer & $\%$ & Değer & $\%$ \\
\hline Brüt üretim değeri (A) & 23.799 & 100 & 80.328 & 100 & 210.725 & 100 & 67.211 & 100 \\
\hline Değişken giderler (B) & 17.252 & 72 & 49.552 & 62 & 145.339 & 69 & 44.599 & 66 \\
\hline Brüt kar (A-B) & 6.547 & 28 & 30.776 & 38 & 65.386 & 31 & 22.612 & 34 \\
\hline Brüt üretim değeri (A) & 23.799 & 100 & 80.328 & 100 & 210.725 & 100 & 67.211 & 100 \\
\hline Üretim giderleri (C) & 26.020 & 109 & 68.398 & 85 & 179.866 & 85 & 60.204 & 90 \\
\hline Net kar (A-C) & -2.221 & -9 & 11.930 & 15 & 30.859 & 15 & 7.007 & 10 \\
\hline Oransal kar $(\mathrm{A} / \mathrm{C})$ & \multicolumn{2}{|c|}{0,91} & \multicolumn{2}{|c|}{1,17} & \multicolumn{2}{|c|}{1,17} & \multicolumn{2}{|c|}{1,12} \\
\hline
\end{tabular}

\section{Sonuç ve Öneriler}

İzmir ili süt sığırcılığı işletmelerinin ekonomik yönden analiz etmek amacıyla yapılan bu çalışmada, Ödemiş, Tire, Kiraz ve Bayındır ilçelerinde süt sı ğırcılı̆̆ 1 yapan 67 işletme ile görüşülmüştür. İncelenen işletmelerin ortalama hayvan sayıs 49 , ortalama inek sayıs 22 ve ortalama günlük süt verimi $22 \mathrm{~kg} /$ baş olarak hesaplanmıştır.

İşletmelerin aktif sermayesinin en büyük bölümünü (\%40) yem bitkisi arazisi oluşturmaktadır. Pasif sermaye içindeki yabanc1 sermayenin oranı sadece \%2'dir. Dolayısıyla işletmeler çoğunlukla kendi öz sermayeleri ile üretim yapmaktadır. Araştırma bölgesinde üretim giderlerinin \%74'ünü değişken giderler, değişken giderlerin \%78'ini yem giderleri oluşturmaktadır. Brüt üretim değerinin \%61'i süt satışından elde edilmektedir.

Çalışma sonuçları, öncelikle büyük işletmelerin, daha sonra da orta büyüklükteki işletmelerin daha karlı olduğunu ortaya çıkarmıştır. Küçük işletmelerin net kârı negatif olarak tahmin edilmiştir. Dolayısıyla küçük işletme ölçeği bir dezavantaj oluşturmaktadır. Bu işletmelerde kesif yem kullanımını mera lehine çevirmek, işletme kârını önemli ölçüde arttırabilecektir.

Sonuç olarak serbest piyasada oluşan düşük düzeydeki süt fiyatları, işletmelerin yıllara göre gelirlerinde önemli farklılıklar yaratmaktadır. $\mathrm{Bu}$ durum özellikle küçük işletmelerin zarar görmesine neden olmaktadır. Dolayısıyla süt üreticilerinin, özellikle de küçük üreticilerin, ancak üretici örgütleri içinde rekabet şansına sahip olabileceği söylenebilir.

\section{Kaynaklar}

Açıl AF, Demirci R. 1984. Tarım Ekonomisi. Ankara Üniversitesi Ziraat Fakültesi Yayınları No: 880, Ankara, Türkiye.

Aras A. 1988. Tarım Muhasebesi. Ege Üniversitesi Ziraat Fakültesi Yayınları No:486, ISBN:975-483-016-9.

Altıntaş G, Akçay Y. 2007. Tokat ili Erbaa Ovasında Tarım İşletmelerinin Ekonomik Analizi ve İşletmelerin Başarısını Etkileyen Faktörlerin Ortaya Konulmas1. Gaziosmanpaşa Üniversitesi Ziraat Fakültesi Dergisi, 24(2): 33-42.

Ata N, Y1lmaz H. 2015. Türkiye'de Uygulanan Hayvansal Üretimi Destekleme Politikalarının Süt Sığırcılığı İşletmelerine Yansımaları: Burdur İli Örneği. Süleyman Demirel Üniversitesi Ziraat Fakültesi Dergisi, 10(1): 44-54.

Bayramoğlu Z. 2003. Konya İli Süt Sığırcılığı Projesi (100x2) Kapsamında Yer Alan İşletmelerin Ekonomik Analizi, Yüksek Lisans Tezi, Fen Bilimleri Enstitüsü, Selçuk Üniversitesi, Konya, Türkiye.

Bayramoğlu Z, Direk M. 2006. Konya ilinde Tarımsal Kalkınma Kooperatiflerinin Ortağı Olan işletmelerde Süt Siğırcılığı Faaliyetinin Ekonometrik Analizi. Selçuk Üniversitesi Ziraat Fakültesi Dergisi, 20(40): 12-20.

Demir P, Aral Y, Sarı̈zkan S. 2014. Kars İli Süt Sığıırcılık İşletmelerinin Sosyo-Ekonomik Yapısı ve Üretim Maliyetleri. Yüzüncü Yıl Üniversitesi Veterinerlik Fakültesi Dergisi, 25(1): 1-6.

Demircan V, Binici T, Köknaroğlu H, Aktaş AR. 2006. Economic Analysis of Different Dairy Farm Sizes in Burdur Province in Turkey. Czech Journal of Animal Science, 51(1): 8-17.

Erkuş A, Turan A, Eliçin A, Tanrıvermiş H, Özçelik A, Gündoğmuş E. 1996. Tekirdağ İli Tarım işletmelerinde İthal ve Kültür Melezi Süt Sığırları ile Üretim Yapan İşletmelerde Süt Sı ğırcılı̆̆ Analizi. Türk Ziraat Yüksek Mühendisleri Birliği ve Vakfı Yayınları N0:14, Ankara, Türkiye. 
Gündüz O, Dağdeviren M. 2011. Bafra İlçesinde Süt Maliyetinin Belirlenmesi ve Üretimi Etkileyen Faktörlerin Fonksiyonel Analizi. Yüzüncü Y1l Üniversitesi Ziraat Fakültesi Tarım Bilimleri Dergisi, 21(2): 104-111.

Günlü A, İmik H, Tekerli M. 2001. Afyon İli Süt Sığırcılığı İşletmelerinin Genel Özellikleri ile Karlılık ve Verimlilik Analizleri. Lalahan Hayvancılık Araştırma Enstitüsü Dergisi, 41(1): 1-12.

GTHB, 2017. Gıda Tarım ve Hayvancılık Bakanlığı. Erişim: http://www.tarim.gov.tr/ sgb/Belgeler/ SagMenuVeriler/ HAYGEM.pdf [Erişim Tarihi: 07 Şubat 2017].

Hanrahan L, McHugh N, Hennessy T,.Moran B, Kearney R, Wallace M, Shalloo L. 2017. Factors Associated with Profitability in Pasture-Based Systems of Milk Production. Journal of Dairy Science, 101: 5474-5485.

İçöz Y. 2004. Bursa İli Süt Sığırcılık İşletmelerinin Karlılık ve Verimlilik Analizi, Yayın No:116, ISBN 975-407-148-9, Ankara, Türkiye.

İDSYB, 2017. İzmir Damızlık Sığır Yetiştiricileri Birliği. Erişim: http://www.izmirbirlik.com/ [Erişim tarihi 17 Nisan 2020].

İnan İH. 1994. Tarım Ekonomisi. Hasat Yayıncılık, Genişletilmiş 3. Bask1, Tekirdağ, Türkiye

Keskin G, Dellal İ. 2011. Trakya Bölgesinde Süt Sığırcılığı Üretim Faaliyetinde Brüt Kar Analizi. Kafkas Üniversitesi Veterinerlik Fakültesi Dergisi, 17(2): 177-182.

Kıral T, Kasnakoğlu H, Tatlidil FF, Fidan H, Gündoğmuş E. 1999. Tarımsal Ürünler İçin Maliyet Hesaplama Metodolojisi ve Veri Tabanı Rehberi. Proje Raporu 1999-13, Tarımsal Ekonomi Araştırma Enstitüsü Yayınları No: 37, Ankara, Türkiye.

Lapple D, Hennessy T, O’Donovan M. 2012. Extended Grazing: A Detailed Analysis of Irish Dairy Farms. Journal of Dairy Science, 95: 188-195.

Miran B. 2002. Temel İstatistik, Ege Üniversitesi Basımevi, ISBN:975-93088-0-0.

Mumba C, Samui KL, Pandey GS, Tembo G. 2012. Econometric Analysis of the Socio-Economic Factors Affecting the Profitability of Smallholder Dairy Farming in Zambia. Livestock Research for Rural Development, Article Number: $66,24(4)$.

Murat H. 2011. Ege ve Orta Anadolu Bölgesi Damızlık Sığır Yetiştiricileri Birliğine Bağlı Süt Sığırcılık İşletmelerinin Ekonomik Analizi. Doktora tez çalışması, Sağlık Bilimleri Enstitüsü, Ankara Üniversitesi, Ankara, Türkiye.

Murat H, Sakarya E. 2012. Orta Anadolu Bölgesi Damızlık Sığır Yetiştirici Birliklerine Bağlı Süt Sığırcılık İşletmelerinin Ekonomik Analizi. Veteriner Hekimler Derneği Dergisi, 83(1): 5-14.

Newbold P, 1995. Statistics for Business and Economics, Prentice-Hall International, New Jersey. USA, ISBN: 013188090X.

Nizam S. 2006. Aydın İlinde Pazara Yönelik Süt Sığırcılığı İşletmelerinin Verimliliklerinin Belirlenmesi. Yüksek Lisans Tezi, Fen Bilimleri Enstitüsü, Adnan Menderes Üniversitesi, Aydın, Türkiye.

Oğuz C, Yener A. 2017. Economic Analysis of Dairy Cattle Enterprises: The Case of Konya Province. European Countryside, 9(2): 263-273.
Özsayın D. 2019. Economic Analysis of Dairy Cattle Farms in Turkey: A Case of Karacabey District. Türk Tarım ve Doğa Bilimleri Dergisi, 6(4): 759-765.

Öztürk D, Karkacıer O. 2008. Süt Sığırcılığı Yapan İşletmelerin Ekonomik Analizi (Tokat İli Yesilyurt İlçesi Örneği). Gazi Osmanpaşa Üniversitesi Ziraat Fakültesi Dergisi, 25(1): 1522.

Özüdoğru T. 2010. Amasya Damızlık Sı̆̆ır Yetiştiricileri Birliğinin Yöre Çiftçilerine Ekonomik Etkilerinin Analizi. Doktora tez çalışması, Fen Bilimleri Enstitüsü, Ankara Üniversitesi, Ankara, Türkiye.

Saner G. 1993. İzmir Yöresinde Pazara Yönelik Süt Sığırcılığı İşletmelerinin Ekonomik Açıdan Değerlendirilmesi Üzerine Bir Araştırma. Doktora tez çalışması, Fen Bilimleri Enstitüsü, Ege Üniversitesi, İzmir, Türkiye.

Semerci A, Parlakay O, Çelik AD. 2015. Hatay İlinde Süt Üretiminin Ekonometrik Analizi. XI. Ulusal Tarım Ekonomisi Kongresi Bildirileri, Samsun, Türkiye, 3-5 Eylül 2014.

Singh KM, Meena MS, Bharati RC, Kumar A. 2012. An Economic Analysis of Milk Production in Bihar. Indian Journal of Animal Sciences, 82(10): 1233-1237.

Şahin K. 2001. Kayseri İlinde Süt Sığırcılığı Yapan İşletmelerin Yapısal Özellikleri ve Pazarlama Sorunları. Yüzüncü Y1l Üniversitesi Ziraat Fakültesi Tarım Bilimleri Dergisi, 11(1): 79-86.

Şahin K, Gül A, Koç B, Dağıstan E. 2001. Adana İlinde Entansif Süt Sığırcılığı Üretim Ekonomisi. Yüzüncü Yıl Üniversitesi Ziraat Fakültesi Tarım Bilimleri Dergisi, 11(2): 19-28.

Tandoğan M. 2006. Afyon İli Süt Sığırcılığı İşletmelerinde Karlılık Analizi ile İşletmelerde Karşılaşılan Üretim ve Pazarlama Sorunları. Yüksek Lisans Tezi, Sağlık Bilimleri Enstitüsü, Kocatepe Üniversitesi, Afyon, Türkiye.

Tokmak T, Ünalan A, Çiçek R. 2011. Niğde İli Süt Siğırcılığı İşletmelerinin Ekonomik Analizi. 7. Ulusal Zootekni Bilim Kongresi Bildirileri, Adana, Türkiye, 14-16 Eylül 2011.

TCMB, 2020. Türkiye Cumhuriyeti Merkez Bankası. Günlük Döviz Kurları. Erişim: https://www.tcmb.gov.tr/kurlar/ kur2017_tr.html, [Erişim tarihi 14 Haziran 2020].

TUIK, 2020a. Türkiye İstatistik Kurumu. Bitkisel ve Hayvansal Üretim Değerleri. Erişim: http://www.tuik.gov.tr/ UstMenu.do?metod=temelist, [Erişim Tarihi: 26.06.2020].

TUIK, 2020b. Türkiye İstatistik Kurumu. Süt ve Süt Ürünleri Üretimi. Erişim: http://www.tuik.gov.tr/PreHaberBultenleri, [Erişim Tarihi: 26.06.2020].

Uddin MM, Sultana MN, Ndambi OA, T Hemme T, Peters KJ. 2010. A Farm Economic Analysis in Different Dairy Production Systems in Bangladesh. Livestock Research for Rural Development, Article Number: 122, 22(7).

Venkatesh P, Sangeetha V. 2011. Milk Production and Resource Use Efficiency in Madurai District of Tamil Nadu: An Economic Analysis. Journal of Community Mobilization and Sustainable Development, 6(1): 25-30.

Yıldırım İ, Şahin A. 2003. Van İli Merkez İlçede Süt Sığırcılığı Yapan İşletmelerin Ekonomik Analizi. Van Ticaret Borsası Yayınları No:1, Van, Türkiye.

Yılmaz H. 2010. Süt Siğırcılığında Kooperatifler Aracılığıyla Desteklemenin Ekonomik ve Sosyal Etkileri: Adana İli Örneği. Doktora tez çalışması, Fen Bilimleri Enstitüsü, Çukurova Üniversitesi, Adana, Türkiye. 